\title{
DOES TOTAL FACTOR PRODUCTIVITY CONVERGE AMONG ASEAN COUNTRIES?
}

\author{
Badri Narayan Rath ${ }^{1}$ \\ ${ }^{1}$ Department of Liberal Arts, Indian Institute of Technology Hyderabad, India, Email: badri@iith.ac.in
}

\begin{abstract}
This paper examines the productivity convergence of the five original Association of Southeast Asian Nations (ASEAN) countries, namely Indonesia, Malaysia, Philippines, Singapore, and Thailand (ASEAN-5), using annual data spanning the period 1968 to 2014. Results from two-break Lagrange multiplier and residual augmented least squares Lagrange multiplier unit root tests reveal strong evidence of productivity convergence in case of ASEAN-5. Further, the results based on Phillips-Sul panel club convergence also reveal productivity convergence. To check the robustness of our finding, we use an alternative measure of total factor productivity and still find evidence of convergence. We infer that such productivity improvements may help ASEAN countries to achieve a higher pace of economic growth.
\end{abstract}

Keywords: Total factor productivity; Convergence; Lagrange multiplier; ASEAN.

JEL Classifications: O47; C22; C23.

Article history:

Received : July 12, 2018

Revised : : September 29, 2018

Accepted : November 30, 2018

Available online : January 31, 2019

https://doi.org/10.21098/bemp.v0i0.962 


\section{INTRODUCTION}

Productivity is, roughly speaking, a measure of how effectively an economy's resources are translated into the production of goods and services. Over long periods, productivity is the single most important determinant of a nation's standard of living (World Employment Report, 2004-2005). In the literature, productivity convergence refers to the "catch up" hypothesis, where countries with lower productivity grow faster to catch up to countries with higher productivity. Seminal works in the literature nicely present the importance of examining the convergence of productivity across countries by using different data sets and diverse techniques to measure it (e.g., Baumol, 1986; Baumol and Wolff, 1988; De Long, 1988; Barro and Sala-i-Martin, 1991; Bernard and Jones, 1996a, 1996b).

This paper investigates whether Total Factor Productivity (TFP) converges among the five major Association of Southeast Asian Nations (ASEAN), that is, Indonesia, Malaysia, Philippines, Singapore, and Thailand (ASEAN-5). The examination of TFP growth convergence is imperative for two reasons. First, an increase in TFP is one of the channels through which a country's standard of living can increase through raising real purchasing power (Krugman, 1994). ${ }^{2}$ Second, according to Baumol et al. (1994), a fairly restricted set of countries can undergo a process that brings their level of productivity and living standards increasingly close to each other by forming a club convergence. In summary, TFP is the most important determinant of economic growth. According to Krugman, "Productivity isn't everything, but, in the long run, it is almost everything" (Krugman, 1994: p. 11). Although a plethora of studies examine income convergence (e.g., Lim and McAleer, 2004; Khorshed, 2005; Jayanthakumaran and Verma, 2008; Masron and Yusop, 2008; Wang, 2012; Solarin et al., 2014) and find mixed evidence, to best of our knowledge, none investigate TFP convergence in the ASEAN context. Examination of income convergence among countries tells us whether and how quickly a poor country can catch up to a rich country in terms of per capita income, but it does not necessarily indicate whether the convergence process is due to an increase in productivity or the accumulation of the factors of several inputs. Therefore, examination of productivity convergence reveals the possibility of technology transfer from leader countries to follower countries, which is the key to sustaining growth momentum.

The rapid rise in the economies of the five founding ASEAN member countries with increasing trade openness and their average growth rate of $5.7 \%$ over the last four and half decades provide motivation to examine the issue of productivity convergence. Since these five countries have a common market through the formation of a trade bloc, it is worth examining their productivity convergence. The examination of convergence among trade blocs has been an interesting phenomenon in the growth literature (e.g., Sach and Waner, 1995; Ben-David, 1996; Ben-David and Loewy, 1998; Neogi, 2016). Most studies, except Neogi's (2016), focus on the impact of trade on per capita income and their common conclusion

\footnotetext{
2 In the Solow model, higher technological progress is the key reason for higher TFP. Higher TFP growth attained through Solow's residual increases output growth which in turn, is the reason for a higher standard of living.
} 
is that free trade or international trade causes convergence. Neogi examines the productivity convergence of Asian trade blocs, including ASEAN, and finds no evidence of productivity convergence.

The present study differs from the literature in two ways. First, while Neogi (2016) empirically examines productivity convergence using the standard absolute and conditional convergence, that is, by regressing the productivity growth rates for a group of countries on the initial productivity level, we use Lagrange Multiplier (LM) and Residual Augmented Least Squares LM (RALS-LM) unit root tests with multiple structural breaks to examine TFP convergence. Narayan (2007), Narayan and Smyth (2007), and Mishra and Smyth (2014) have explained the advantages of testing convergence using unit root tests over traditional notion of $\sigma$ and $\beta$ convergence. Convergence analysis through unit root tests examines whether there is a common deterministic trend in the productivity of different countries. The $L M$ and RAS- $L M$ tests allow for breaks point in the series and thus provide robust evidence of the catch up hypothesis for individual countries over the years. These tests also measure the relative productivity growth of a particular country divided by the average productivity of a group, that is, ASEAN-5.

Second, this study uses the panel club convergence method developed by Phillips and Sul (2007, hereafter PS), which allows the analysis of economic transition behavior in the presence of common growth characteristics, adding a methodological contribution to the research literature. The PS approach has certain advantages over the neoclassical approach to the notion of sigma and beta convergence. First, it captures heterogeneity in the panels based on a nonlinear time-varying factor model. Second, it has more power to detect asymptotic comovement with the existence of a unit root. Third, PS convergence captures common transition paths by fitting groups of similar countries into forming clubs.

Third, TFP growth is estimated through both the Törnqvist index and a welfare-relevant TFP index developed by Feenstra et al. (2015) to examine productivity convergence among countries The welfare-based productivity index is very relevant to our comparison of the productivity for each country over time and therefore the welfare measure of TFP and the Törnqvist index are used in the robustness checks. To best of our knowledge, this study contributes to the productivity convergence literature, particularly in the case of ASEAN-5.

This study uses annual data on ASEAN-5 members from 1968 to 2014. Our approach, based on $L M$ and RALS-LM unit root tests and the PS panel convergence method, offers the following insights. First, the empirical results based on $L M$ and RALS-LM unit root tests with two/one/zero breaks provide evidence of productivity convergence in the case of ASEAN-5. Second, the results derived from PS also show evidence of the productivity convergence of ASEAN-5 as a club. That means the productivity of the ASEAN-5 countries is converging as a group. Third, the alternative welfare-based TFP index is used and the results again show evidence of productivity convergence in the case of ASEAN-5 countries. From a policy perspective, achieving high levels of productivity and sustaining them among the ASEAN-5 should be the target.

The remainder of this paper is organized as follows. Section II reviews the literature. Section III describes the methodology and the data. Section IV presents the empirical results and final Section $\mathrm{V}$ concludes the paper. 


\section{LITERATURE REVIEW}

Many studies on convergence in both the theoretical and empirical literature have focused almost exclusively on aggregate income, output, and productivity. Despite vast numbers of studies on income convergence among industrial as well as developing countries, studies on productivity convergence that emphasize trade blocs are scant. Nevertheless, this section briefly reviews some seminal works that analyze productivity convergence at both the aggregate and sectoral levels.

Baumol (1986) examines productivity convergence using annual data from 16 countries and finds evidence of labor productivity convergence. Dollar and Wolff (1988) investigate the productivity convergence of manufacturing industries from 1963 to 1982 in 13 industrialized countries. Their findings suggest evidence of the convergence of productivity levels in every manufacturing industry. Barro and Sala-i-Martin (1991) disaggregate the nonagricultural part of the gross state product into the value added per worker for eight sectors. The main finding is that convergence is significant within these sectors of production, especially in manufacturing. The main inference from these results is that poorer states grow faster not only in terms of overall gross state product per person, but also in terms of labor productivity within various sectors of production. Similarly, Barro and Sala-i-Martin (1992) analyze per capita income and productivity convergence using a neoclassical growth model across the 48 US states and find convergence, in the sense that economies tend to grow faster in per capita terms the farther they are below their steady-state position.

Bernard and Durlauf (1995) examine the convergence of per capita output using century-long time series data for 15 Organisation for Economic Cooperation and Development (OECD) economies. Their analysis of the relations between long-term output movements across countries reveals little evidence of convergence. Bernard and Jones (1996a) examine the role of sectors in aggregate convergence for 14 OECD countries during the same period by using different measure of productivity. First, they estimate the convergence in labor productivity measures and TFP measures. The major finding is that manufacturing shows little evidence for convergence in all measures, whereas other sectors, especially services, are driving the aggregate convergence result. Bernard and Jones (1996b) further examine whether the TFP convergence in the aggregate economy is also occurring at the industry level in the case of 14 OECD countries, using data from 1970 to 1987 . Using both cross-sectional regression and a panel unit root test, they find strong evidence of aggregate convergence in TFP.

Similarly, Cornwell and Wachter (1998) examine productivity convergence based on frontier production functions for a sample of 26 OECD countries and find convergence and the catch-up effect to be fairly strong among European countries, but not among G-7 countries. Apergis and Christou (2016) examine the energy productivity convergence issue for 31 countries, using annual data from 1972 to 2012. The results, based on the PS technique, document the absence of energy productivity convergence for the full sample but convergence in a number of subgroups. Maryam and Jehan (2018) investigate TFP convergence using data from 93 developing countries. The main objective of their study was to examine the determinants of TFP convergence by emphasizing trade openness and foreign direct investment. They find that, although a high degree of openness benefits TFP growth and convergence, foreign direct investment plays a dominating role. 
In a nutshell, though productivity convergence has gained tremendous importance, further deliberation on trade integration in the productivity catch-up process is required underway. Therefore, this study examines TFP convergence in the case of ASEAN-5, whose five countries share a common market. As Baumol et al. (1994) note, countries of similar economic structure can improve their standards of living through productivity convergence.

\section{METHODOLOGY AND DATA}

\section{A. Measuring Productivity Convergence}

Convergence in empirical growth dynamics has been given much attention, starting with neoclassical growth models to endogenous growth theories. While neoclassical growth model supports evidence of convergence, the endogenous growth model considers the absence of convergence (Islam, 1995). Ample numbers of studies measure convergence using so-call $\sigma$-convergence and $\beta$-convergence. According to neoclassical growth models, $\beta$-convergence arises in a group of economies when the per capita growth rate tends to be inversely related to the starting level of income or output per person (Barro and Sala-i-Martin, 1992). Similarly, in $\sigma$-convergence, the dispersion of real per capita output across groups of economies tends to fall over time. However, both concepts suffer the following limitation. Bliss (2000) and Apergis and Christou (2016) highlight that the absence of $\sigma$-convergence does not necessarily mean that countries do not converge; rather, the presence of transitional dynamics in the data can lead to the rejection of the null hypothesis of $\sigma$-convergence. Similarly, critics of $\beta$-convergence argue that, if each country eventually becomes as rich as all the other countries, then the dispersion of the variable under study should disappear in the long run (Quah, 1993, 1996). Overall, both approaches suffer from estimation issues.

To overcome these specific estimation deficiencies, this paper use the following two approaches to estimate the TFP convergence of ASEAN-5 countries. First, it employs the recently developed $L M$ and RALS-LM unit root tests, which endogenously determine the structural breaks to test the convergence (for a detailed methodology, see Lee et al., 2012; Meng et al., 2014; Mishra and Smyth, 2017). This unit root tests examines the existence of stochastic convergence in relative productivity across ASEAN-5 over time. To be more precise, this study examines, for each country $i$, the natural logarithm of the ratio of TFP in a country relative to the average of all five ASEAN-5 countries. To assess the stochastic conditional convergence, the following equation can be written:

$$
y_{i t}=\ln \left[\frac{T F P_{i t}}{\text { average } T F P_{t}}\right]
$$

where $y$ is the ratio of the TFP of each country in our sample to the average TFP of ASEAN-5 over time for country $i=1,2, \ldots, 5$ and period $t$, from 1968 to 2014 . The $y_{i t}$ series in equation (1) can be tested using $L M$ and RALS-LM unit root tests. The rejection of the null hypothesis of a unit root supports the presence of convergence of TFP of each ASEAN-5 country in relative to their average productivity. 
Second, this study also applies the club convergence method developed by PS. The idea behind applying the PS model is to examine whether the TFP across the ASEAN-5 tends to converge as a club in a panel framework: "[The] PS model is a nonlinear factor model with a growth component and a time varying idiosyncratic component that allows for quite general heterogeneity across individuals and over time" (PS). This test relaxes many assumptions, such as trend stationarity, the stochastic nonstationarity of the variables, and common factors across the countries in the panel.

\section{B. Data and TFP Measurement}

This paper uses annual TFP data from 1968 to $2014^{3}$ for the ASEAN-5 countries. We chose the five founding member countries, namely, Indonesia, Malaysia, Philippines, Thailand, and Singapore, and select data from 1968 because ASEAN was established on August 8, 1967. We collect TFP data from the Penn World Table 9.0, which is provided by Feenstra et al. (2015). The present paper uses two types of TFP. First, the TFP is measured in real terms, using the Törnqvist quantity index in the following manner:

$$
R T F P_{j t, t-1}^{N A}=\frac{R G D P_{j t}^{N A}}{R G D P_{j t-1}^{N A}} / Q_{T}\left(v_{j t}, v_{j t-1}, w_{j t}, w_{j t-1}\right)
$$

where RTFPNA is the real TFP of country $j$ over the period based on national account data, $R G D P^{N A}$ is the real Gross Domestic Product (GDP) based on national account data, $Q_{T}$ is the Törnqvist quantity index of factor endowments based on observed factor prices and shares (Feenstra et al., 2015), and $v$ and $w$ are the income shares of labor and capital inputs, respectively. Then the second approach to TFP is computed based on the welfare-relevant measure.

$$
R W T F P_{j t, t-1}^{N A}=\frac{C D A_{j t}^{N A}}{C D A_{j t-1}^{N A}} Q_{T}\left(v_{j t}, v_{j t-1}, w_{j t}, w_{j t-1}\right)
$$

This measure is not based on the real GDP; rather, it is measured on relative domestic absorption.

\section{RESULTS AND DISCUSSION}

Table 1 presents the preliminary results for the growth rates of the key variables for ASEAN-5. The results can be summarized as follows. First, the growth rates of labor, capital stock, and the real GDP of Singapore in 2014 during 1968 are higher than those of the other ASEAN countries. Labor input grew by $452.5 \%$ in 2014 compared to the labor of 1968. Labor grew by $334.3 \%$ in the case of Malaysia, $228.3 \%$ in Philippines, $223.8 \%$ in Indonesia, and $148.1 \%$ in Thailand during the

3 The choice of first year, i.e., 1968 is based on the evidence of formation of ASEAN in late 1967 and the end period 2014 is purely based on the availability of total factor productivity data in the Penn World Table 9.0 
same period. Similarly, the capital stock growth rates have been impressive for all ASEAN-5 countries, with the highest in Singapore and the lowest in Philippines. The real GDP in 2014 increased tremendously compared to that in 1968 for all ASEAN-5 countries. The TFP measured by the Törnqvist index demonstrate the highest growth in Thailand (59.3\%), followed by Malaysia (21.9\%). However, TFP growth appears to be negative for Philippines (-3\%) in 2014 compared to 1968.

Table 1.

\section{Growth Rate of Key Indicators}

This table presents the growth rates of labour, capital and GDP of ASEAN-5 along with total factor productivity growth. Since labour, capital and GDP are used to estimate the TFP, thus, it is important to show the input and output growth rates along with TFP growth rate of ASEAN-5 from 1968 to 2015.

\begin{tabular}{lcccc}
\hline Country & Labour & Capital & GDP & TFP \\
\hline Indonesia & 223.8 & 1246.7 & 1840.3 & 16.8 \\
Malaysia & 334.3 & 1770.5 & 2925.7 & 21.9 \\
Philippines & 228.3 & 506 & 660.9 & -3 \\
Singapore & 452.5 & 2570.6 & 3502.5 & 18 \\
Thailand & 148.1 & 1586.2 & 1760 & 59.3 \\
\hline
\end{tabular}

After discussing the preliminary results of TFP along with key input and output growth rates, we next present the results of $L M$ and $R A L S-L M$ unit root tests. The results in Table 2 show that the natural logarithm of the ratio of TFP for each of the ASEAN-5 countries to their average TFP. The null hypothesis is the TFP possesses a unit root, that is, nonstationary I(1), as opposed to the alternative hypothesis, that the series follows a stationary process, I(0). The rejection of the null hypothesis of the unit root tests is evidence of convergence. The results in Table 2 report that all ASEAN-5 except Singapore show evidence of productivity convergence. To sum up, the results in Table 2 support the presence of stochastic convergence in relative TFP in the case of ASEAN-5. In the case of Singapore, we are unable to reject the null hypothesis, irrespective of the trend break, thus affirming no convergence. We further examine productivity convergence by employing zero, one, and two trend breaks and the results are presented in Appendix 1. Appendix 1 draws the same conclusion as the results highlighted in Table 2. 
Table 2.

\section{Using Zero/One/Two Breaks LM and RALS-LM Unit Root Test (RTFP)}

This table shows the natural logarithm of the ratio of total factor productivity in each of the founding members of ASEAN to the average total factor productivity of ASEAN-5. The null hypothesis is the total factor productivity possess a unit root, i.e. nonstationary I(1) as against the alternative hypothesis is the series follows a stationary process, $\mathrm{I}(0)$.

\begin{tabular}{|c|c|c|c|c|c|c|}
\hline \multirow{2}{*}{$\begin{array}{l}\text { Total Factor } \\
\text { Productivity }\end{array}$} & \multirow{2}{*}{$\begin{array}{c}\text { LM } \\
\tau^{*} \mathrm{LM}\end{array}$} & \multicolumn{2}{|c|}{ RALS-LM } & \multicolumn{2}{|c|}{$\widehat{T}_{B}$} & \multirow{2}{*}{$\widehat{\boldsymbol{k}}$} \\
\hline & & $\tau^{*}$ RALS-LM & $\widehat{\rho}^{2}$ & $\widehat{T}_{B 1}$ & $\widehat{T}_{B 2}$ & \\
\hline Indonesia & $-4.525^{*}$ & $-5.263^{* * *}$ & 0.71 & 1996 & 2000 & 4 \\
\hline Malaysia & $-7.127^{* * *}$ & $-7.181^{* * *}$ & 0.83 & 1981 & 2008 & 2 \\
\hline Philippines & $-5.179^{* *}$ & $-4.710^{* *}$ & 0.99 & 1981 & 1996 & 8 \\
\hline Singapore & -3.277 & -2.626 & 0.79 & 1977 & 2009 & 4 \\
\hline Thailand & $-6.759^{* * *}$ & $-6.426^{* * *}$ & 0.59 & 1980 & 1986 & 1 \\
\hline
\end{tabular}

Note: The sample period taken from 1968-2014 in our analysis. $\hat{k}$ stands for optimum lags selected using general to specific procedure. $\widehat{T}_{B}$ indicates the break periods. $\tau_{L M}^{*}$ and $\tau_{R A L S-L M}^{*}$ denotes the test statistics for $L M$ and RALS-LM test. $L M$ and $R A L S-L M$ are invariant to the breaks periods. The critical values $L M$ and RALS-LM can be found Meng et al. (2014). ${ }^{* * *},{ }^{* *}$, and ${ }^{*}$ show $1 \%, 5 \%$ and $10 \%$ significance level.

Figure 1 illustrates the logarithm of relative TFP with two trend breaks. It shows productivity trend breaks in 1996 and 2000. A plausible reason for the decline in TFP in Indonesia during 1997-2000 is the 1997 Asian financial crisis. The New Economic Policy launched in Malaysia in 1971 further boosted economic activism in the early 1980s, with the prime minister then, Dr. Mahathir bin Mohamad, announcing a heavy industry project with the key objective of strengthening the manufacturing sector. The budget deficit as a percentage of the gross national product during 1981-1985 was therefore almost three times that for the previous decade. The trend break in TFP in 1981 can be attributed to those factors. Again, the second trend break in 2008 was mainly due to the global financial crisis. Similarly, although we note two trend breaks for Singapore, they are not significant. In Figure 1, the TFP of Philippines shows a downward trend from 1968 to 1981. Philippines's economy was doing well in the 1950s and 1960s after gaining its independence from the United States in 1946. During those two decades, Philippines was the second most progressive country in Asia, after Japan, but it faced problems, especially in the 1970s. In 1972, then-president Ferdinand Marcos declared a state of emergency and, later, in 1981, the country began facing severe debt problem. All these factors led to the plausible decline in the TFP during the mid-1980s. Then, the TFP trend increased in Philippines from the second trend break (1996) on, despite the Asian financial crisis in 1997. The TFP of Thailand shows an upward trend for most periods. 


\section{Figure 1. Log of Relative TFP with Two Trend Breaks (RTFP)}

This figure plots the relative TFP for each country over the sample period 1968 to 2014. The two breaks are also highlighted.

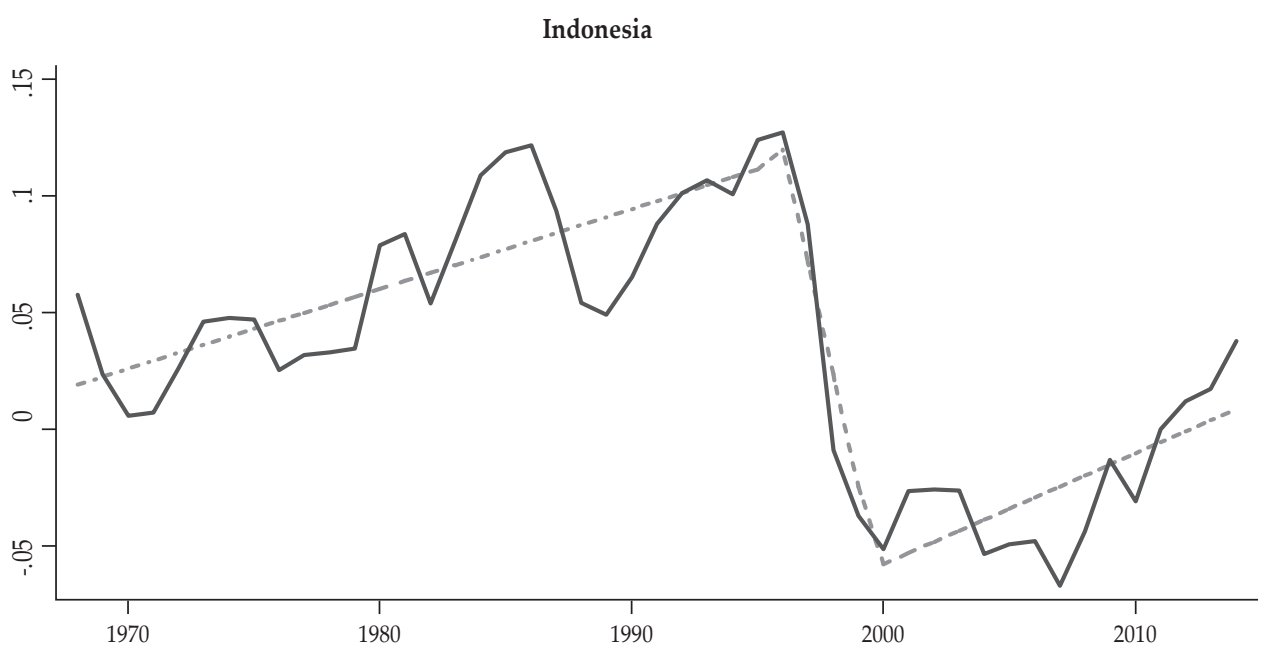

Philippines

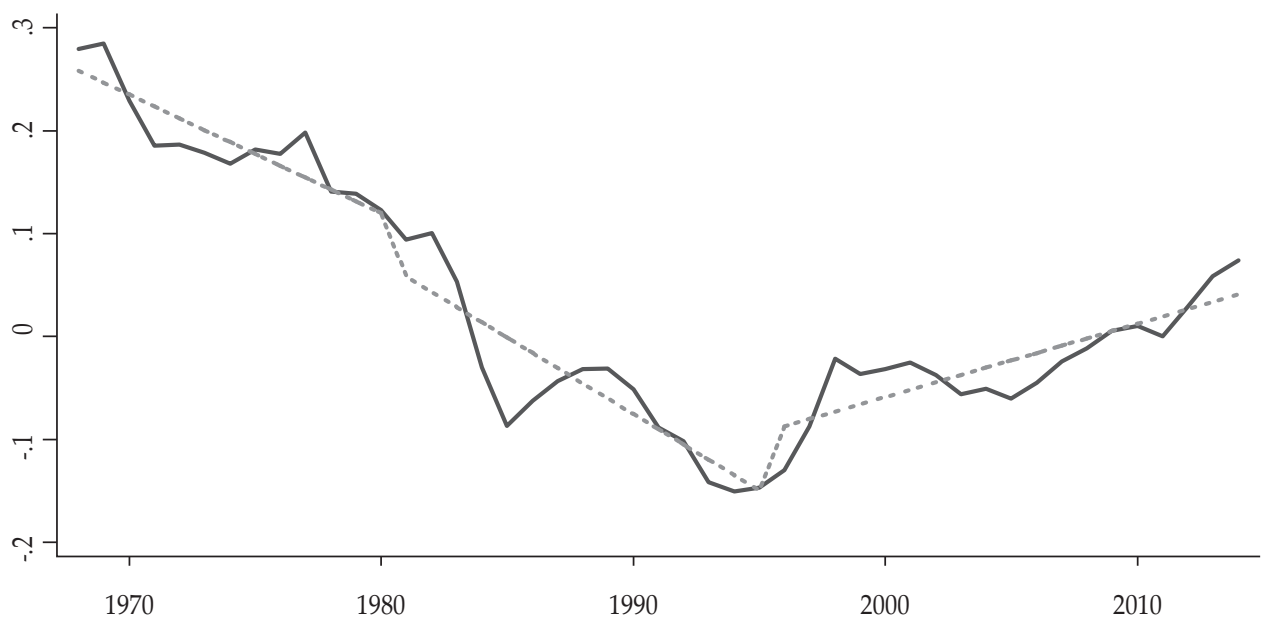



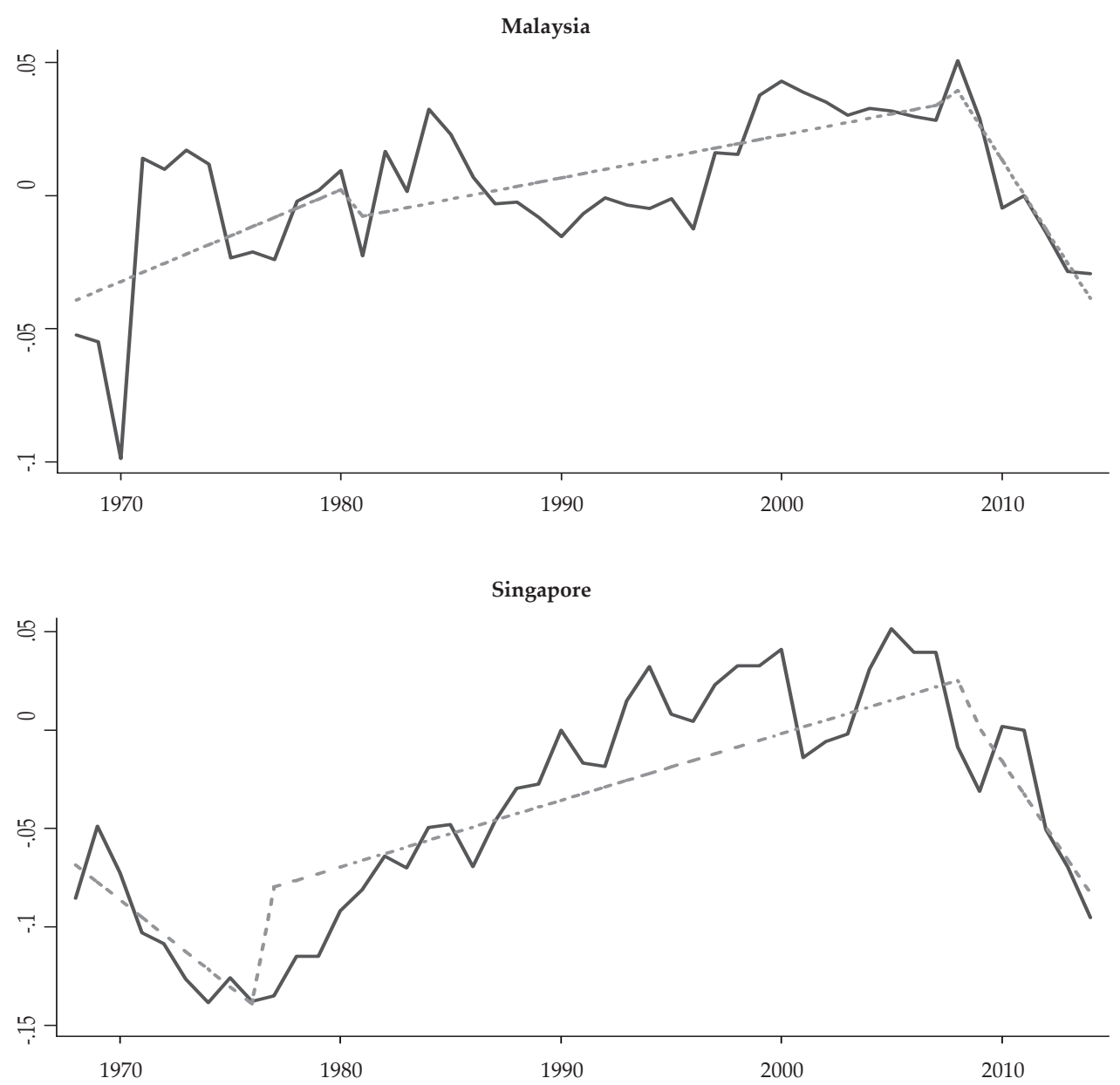

Thailand

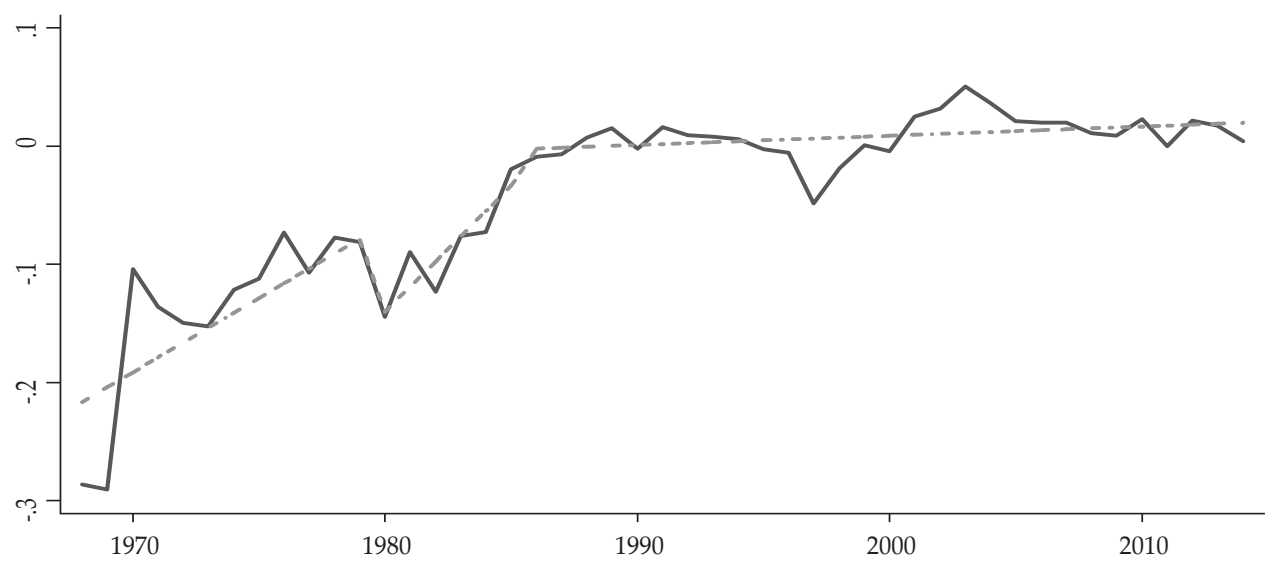


After discussing the $L M$ and RALS-LM based unit root tests, we now present the results of productivity club convergence by employing the PS approach. The advantage of using the PS methodology is briefly explained in the previous section. The results in Table 3 provide evidence of productivity convergence where a club is formed of the ASEAN-5 countries. The second column shows the $\hat{b}$ and $\log (t)$ values, whereas the third column indicates the decision for the null hypothesis. According to PS, the null hypothesis holds in the presence of convergence. Our results demonstrate that, for ASEAN-5, $\log (t)=-1.138$, which is above the critical value (i.e., $t_{\hat{b}}<-1.65$ at the $5 \%$ level of significance). Thus, the results of Table 3 accept the null hypothesis, indicating evidence of TFP convergence in the case of ASEAN-5 countries.

Table 3.

TFP Club Convergence (RTFP)

This table illustrates the results of total factor productivity convergence obtained using Phillips and Sul (2007) panel club convergence technique. The critical value of $t$-stat. is -1.67 at the $5 \%$ level of significance and the calculated $t$-stat. is presented in parentheses. Finally, ${ }^{* *}$ indicates the acceptance of null of convergence at $5 \%$ level of significance.

\begin{tabular}{lccc}
\hline \multirow{2}{*}{ Clubs } & Country & $\begin{array}{c}b \text {-Coefficient } \\
{[t \text {-stat }]}\end{array}$ & Decision \\
\hline Full sample & Indonesia, Malaysia, Philippines, Singapore, & $-2.047^{* *}$ & Convergence \\
& Thailand & {$[-1.138]$} & \\
\hline
\end{tabular}

\section{Robustness Check}

This section presents the robustness of the results that we obtained above section by employing an alternative welfare-based TFP measure using Equation (3).

We once again apply both $L M$ and $R A L S-L M$ unit root tests and PS panel club convergence methods to the welfare-based TFP index (RWTFP) data. The LM and RALS-LM welfare-based unit root tests results are reported in Table 4 and Figure 2. Appendix 2 provides further country-specific results for the $L M$ and RALS-LM unit root tests based on zero, one, and two trend breaks. The results based on PS club convergence are presented in Table 5. To sum up, the results based on welfare-based TFP also provide evidence of productivity convergence in the case of the ASEAN-5 countries. However, we note two differences while comparing the results of productivity convergence based on welfare-based TFP with the results derived from the first measure of TFP (i.e., RTFP, using equation (2)): First, the results based on welfare-adjusted TFP indicate that Singapore's productivity converges to the average productivity of ASEAN-5, at the $1 \%$ significance level. Second, since the welfare-based TFP index is measured based on relative domestic absorption and not on the real GDP, the trend break periods are different. 


\section{Table 4.}

\section{Using Zero/One/Two Breaks LM and RALS-LM Unit Root Test (RWTFP)}

This table presents the results of LM \& RALS-LM unit root tests using welfare based TFP index (RWTFP). The sample period taken from 1968-2014 in our analysis. $\hat{k}$ stands for optimum lags selected using general to specific procedure. $\widehat{T}_{B}$ indicates the break periods. $\tau_{L M}^{*}$ and $\tau_{R A L S-L M}^{*}$ denotes the test statistics for LM and RALS-LM test. LM and RALS-LM are invariant to the breaks periods. The critical values LM and RALS-LM can be found Meng et al. (2014). ${ }^{* * *},{ }^{* *}$, and * show $1 \%, 5 \%$ and $10 \%$ significance level. convergence at $5 \%$ level of significance.

\begin{tabular}{lcccccc}
\hline \multirow{2}{*}{ Total Factor Productivity } & LM & \multicolumn{2}{c}{ RALS-LM } & \multicolumn{2}{c}{$\widehat{\boldsymbol{T}}_{\boldsymbol{B}}$} & \multirow{2}{*}{$\widehat{\boldsymbol{k}}$} \\
\cline { 2 - 6 } & $\boldsymbol{\tau}_{\boldsymbol{L M}}^{*}$ & $\boldsymbol{\tau}_{\boldsymbol{R} \boldsymbol{A} \boldsymbol{L} \boldsymbol{S}-\boldsymbol{L M}}$ & $\widehat{\boldsymbol{\rho}}^{\mathbf{2}}$ & $\widehat{\boldsymbol{T}}_{\boldsymbol{B} \mathbf{1}}$ & $\widehat{\boldsymbol{T}}_{\boldsymbol{B} \mathbf{2}}$ & \\
\hline Indonesia & $-6.367^{* * *}$ & $-6.351^{* * *}$ & 0.87 & 1997 & 2004 & 8 \\
Malaysia & $-2.925^{*}$ & -2.369 & 0.95 & - & - & 0 \\
Philippines & $-5.686^{* * *}$ & $-6.057^{* * *}$ & 0.85 & 1996 & 2004 & 1 \\
Singapore & $-5.312^{* * *}$ & $-6.290^{* * *}$ & 0.75 & 1999 & 2004 & 2 \\
Thailand & $-5.709^{* * *}$ & $-6.017^{* * *}$ & 0.72 & 1978 & 1983 & 3 \\
\hline
\end{tabular}

Figure 2. Log of Relative TFP with Two Trend Break (RWTFP)

This figure plots the welfare based TFP index (RWTFP) for each country over the sample period 1968 to 2014. The two breaks are also highlighted.

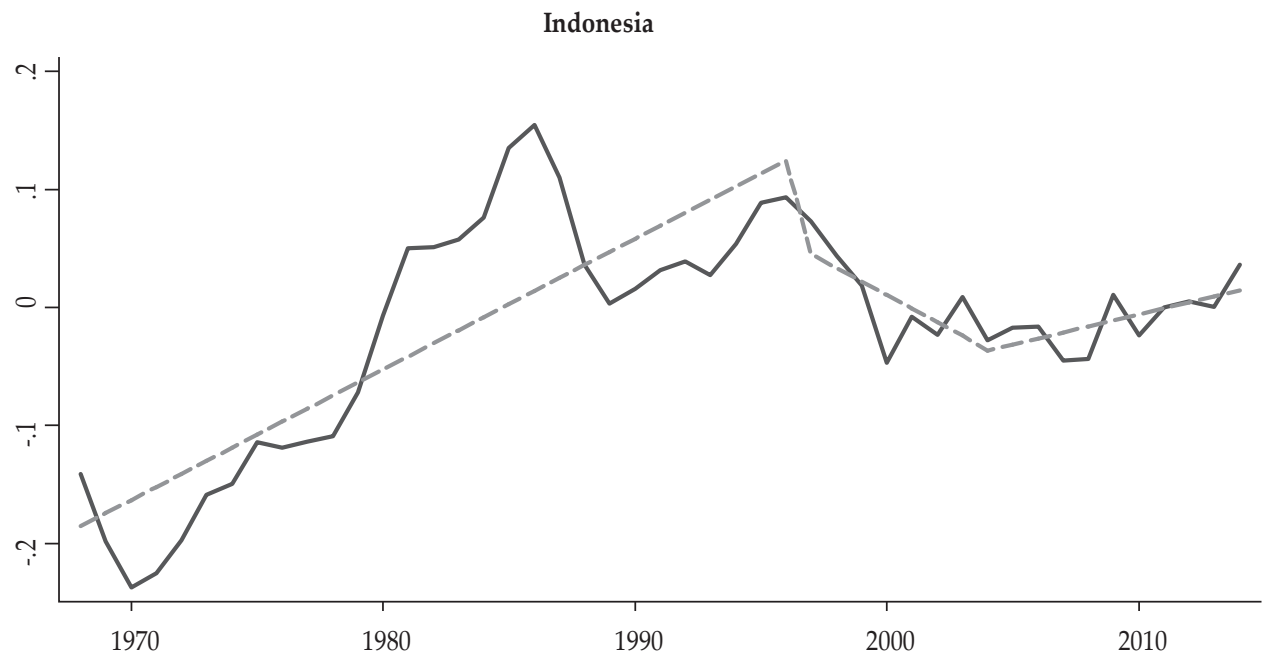


Philippines
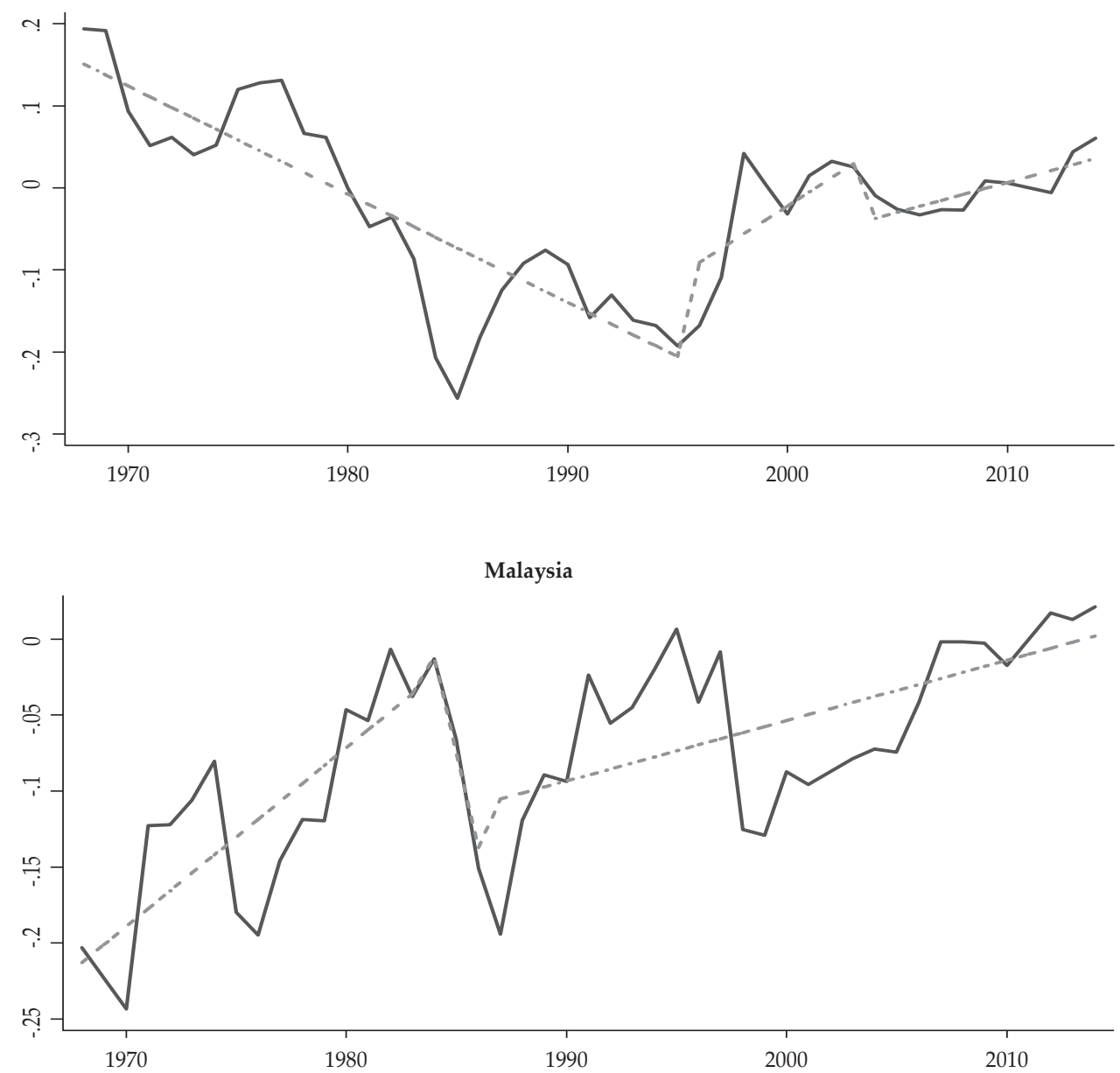

Singapore

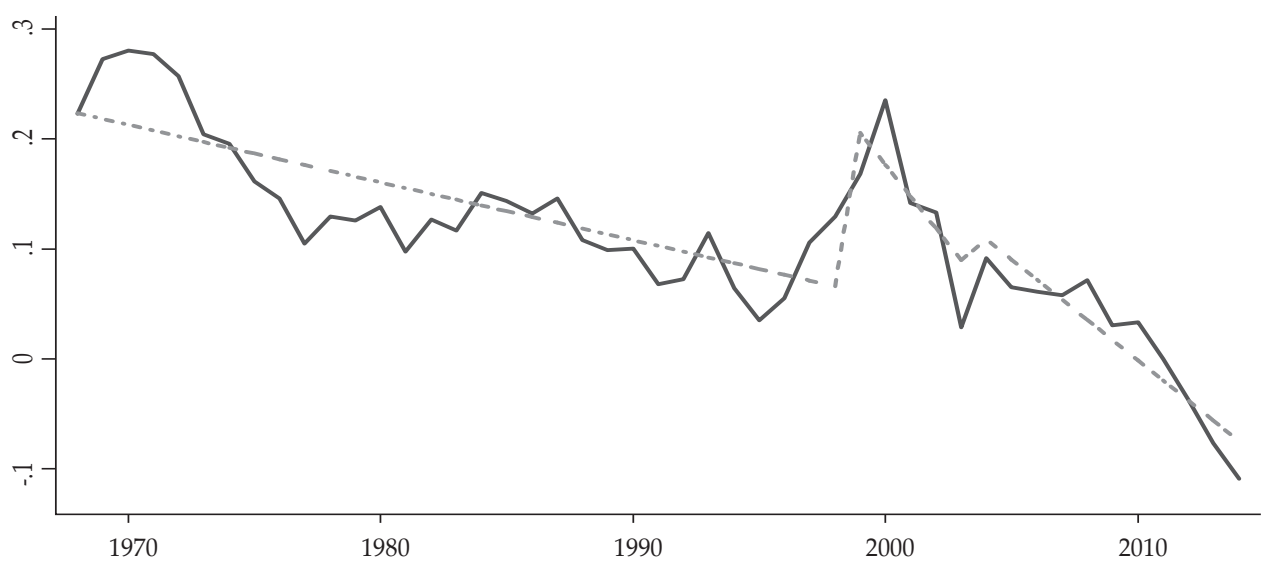




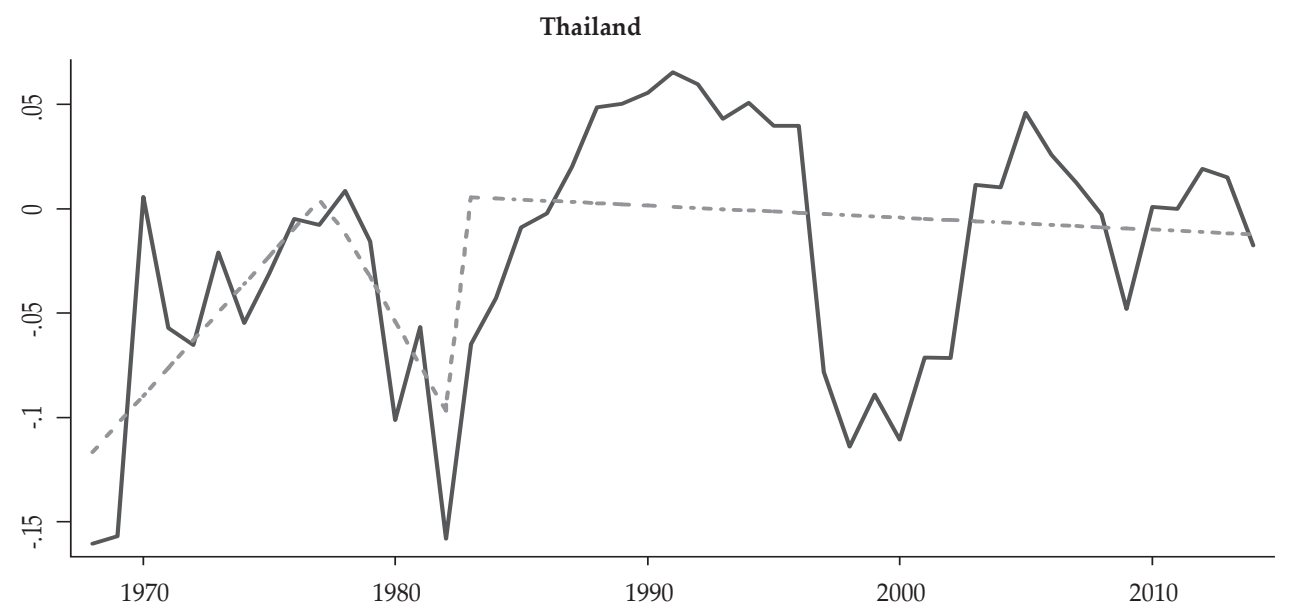

Table 5.

WTFP Club Convergence

This table illustrates the results of welfare based total factor productivity convergence using Phillips and Sul (2007) panel club convergence technique. The critical value of $t$-stat. is -1.67 at the $5 \%$ level of significance and calculated $t$-stat. is presented in parentheses. Finally, ${ }^{* *}$ indicates the acceptance of null of convergence at the $5 \%$ level of significance.

\begin{tabular}{lccc}
\hline Clubs & Country & $b$-Coefficient $[t$-stat] & Decision \\
\hline \multirow{2}{*}{ Full sample } & Indonesia, Malaysia, Philippines, & $4.910^{* *}$ & \multirow{2}{*}{ Convergence } \\
& Singapore, Thailand & {$[3.415]$} & \\
\hline
\end{tabular}

\section{CONCLUSION}

This study explores the productivity convergence for the five ASEAN- 5 countries from 1968 to 2014. To examine this issue, the paper uses i) LM and RALS-LM unit root tests and ii) PS panel club convergence methods. The results from $L M$ and RALS-LM unit root tests with two breaks reveal strong evidence of productivity convergence in the case of the ASEAN- 5 countries. Further, the results based on PS panel convergence also exhibit productivity convergence in the case of ASEAN-5 as a club. To check the robustness of our findings, we use an alternative measure of TFP and the results show evidence of convergence in the case of ASEAN-5. This finding demonstrates that policies in Southeast Asian countries should be targeted at further enhancing productivity to maintain high sustained economic growth.

Acknowledgement: The author gratefully acknowledges the suggestions of Dr. Bernard Njindan Iyke, Professor Paresh Kumar Narayan and other participants of 12th BMEB International Conference, Bali, Indonesia, August 2018. The author also acknowledges the help from Dr. Vindo Mishra and Dr. Kerui Du for sharing LM \& RALS-LM unit root tests and Phillips and Sul club convergence estimation codes, respectively. The assistance provided by Vaseem Akram is gratefully acknowledged. The usual disclaimer applies. 


\section{REFERENCES}

Apergis, N. and Christou, C. (2016). Energy Productivity Convergence: New Evidence from Club Converging. Applied Economic Letters, 23, 142-145.

Barro, R. J. and Sala-i-Martin, X. (1991). Convergence Across States and Regions. Brooking Papers Economic Activity, 1, 107-182.

Barro, R.J. and Sala-i-Martin, X. (1992). Convergence. Journal of Political Economy, 100, 223-251.

Baumol, W. J. and Wolff, E.N. (1988). Productivity Growth, Convergence, and Welfare: Reply. American Economic Review, 78, 1155-1159.

Baumol, W. J. (1986). Productivity Growth, Convergence, and Welfare: What the Long Run Data Show. American Economic Review, 76, 1072-1085.

Baumol, W. J., Nelson, R. R. and Wolff, E.N. (1994). Convergence of Productivity: Cross-National Studies and Historical Evidence. Oxford University Press.

Ben-David, D. and Loewy, M. B. (1998). Free Trade, Growth, and Convergence. Journal of Economic Growth, 3, 143-170.

Ben-David, D. (1996). Trade and Convergence Among Countries. Journal of International Economics, 40, 279-298.

Bernard, A. B., and Jones, Charles I. (1996a). Comparing Apples to Oranges: Productivity Convergence and Measurement Across Industries and Countries. American Economic Review, 86, 1216-1238.

Bernard, A. B., and Jones, Charles I. (1996b). Productivity Across Industries and Countries: Time Series Theory and Evidence. Review of Economics and Statistics, 78, 135-146.

Bernard, A. B., and Durlauf, Steven N. (1995). Convergence in International Output. Journal of Applied Econometrics, 10, 97-108.

Bliss, C. (2000). Galton's Fallacy and Economic Convergence: A Reply to Cannon and Duck. Oxford Economic Papers, 52, 420-422.

Cornwell, M.C and Wachter, Jens-Uwe. (1998). Productivity Convergence and Economic Growth: A Frontier Production Function Approach, Zentrumfür Europäische Integrationsforschung. Working Paper, 6, (http: //www.zei.de).

De Long, J. B. (1988). Productivity Growth, Convergence, and Welfare: Comment. American Economic Review, 78, 1138-54.

Feenstra, Robert C., Inklaar, R., and Timmer, Marcel P. (2015). The Next Generation of the Penn World Table. American Economic Review, 105, 3150-3182.

Islam, Nazrul. (1995). Growth Empirics: A Panel Data Approach. Quarterly Journal of Economics, 110, 1127-1170.

Jayanthakumaran, K., and Verma, R. (2008). International Trade and Regional Income Convergence: The ASEAN-5 Evidence. ASEAN Economic Bulletin, 25, 179-194.

Krugman, P. (1994). The Age of Diminished Expectations: U.S. Economic Policy in the 1990s. Third Edition, MIT Press.

Lee, J., Strazicich, M.C., and Meng, M. (2012). Two-Step LM Unit Root Tests with Trend Breaks. Journal of Statistical and Econometric Methods, 1, 81-107.

Lim, L., and Mcaleer, M. (2004). Convergence and Catching Up in ASEAN: A Comparative Analysis. Applied Economics, 36, 137-153. 
Maryam, K., and Jehan, Z. (2018). Total Factor Productivity Convergence in Developing Countries: Role of Technology Diffusion. South African Journal of Economics, https://doi.org/10.1111/saje.12189

Masron, T. A., and Yusop, Z. (2008). AFTA, Income Growth and Income Convergence in ASEAN, The International Trade Journal, 22, 290-314.

Meng, M., K. Im, J. Lee, and Tieslau, M. (2014). More Powerful LM Unit Root Tests with Non-Normal Errors. The Festschrift in Honor of Peter Schmidt, edited by R. Sickles and W. Horrace, 343-357. Germany: Springer Publishing Co.

Mishra, V. and Smyth, R. (2014). Convergence in Energy Consumption Per Capita Among ASEAN Countries. Energy Policy, 73, 180-185.

Mishra, V. and Smyth, R., (2017). Conditional Convergence in Australia's Energy Consumption at Sector Level. Energy Economics, 62, 396-403.

Narayan, P. K. and Smyth, R., (2007). Are Shocks to Energy Consumption Permanent or Temporary? Evidence from 182 Countries. Energy Policy, 35, 333341.

Narayan, P. K. (2007). Do Health Expenditures 'Catch Up'? Evidence from OECD Countries. Health Economics, 16, 993-1008.

Neogi, C., (2016). Productivity Convergence and Asian Trade Blocs. In Handbook of Research on Global Indicators of Economic and Political Convergence (Ed) by R. C. Das, IGI Global, Ch. 5: 92-118.

Phillips, P.C.B., and Sul, D. (2007). Transition Modeling and Econometric Convergence Tests. Econometrica, 75, 1771-1855.

Quah, D., (1993). Galton's Fallacy and the Tests of the Convergence Hypothesis. Scandinavian Journal of Economics, 95, 427-443.

Quah, D., (1996). Twin Peaks: Growth and Convergence in Models of Distribution Dynamics. The Economic Journal, 106, 1045-55.

Sachs, J., D., and Warner, A., M. (1995). Economic Convergence and Economic Policies. CASE Network Studies and Analyses No. 35. Available at SSRN: https://ssrn.com/abstract=1479610 or http://dx.doi.org/10.2139/ssrn.1479610

Solarin, S. A., Ahmed, E. M., and Dahalan, J. (2014). Income Convergence Dynamics In ASEAN and SAARC Blocs. New Zealand Economic Papers, 48, 285-300.

Wang, M. S. (2012). Income Convergence within ASEAN, ASEAN+3: a Panel Unit Root Approach. Applied Economic Letters, 19, 417-423.

World Employment Report. (2004-05). Employment, Productivity and Poverty Reduction. International Labour Organization, Geneva. 


\section{Appendix 1. \\ Using Zero/One/Two Breaks LM and RALS-LM Unit Root Test (RTFP)}

This table reports the unit root test results for relative TFP. The sample period taken from 1968-2014 in our analysis. $\hat{k}$ stands for optimum lags selected using general to specific procedure. $\widehat{T}_{B}$ indicates the break periods. $\tau_{L M}^{*}$ and $\tau_{R A L S-L M}^{*}$ denote the test statistics for LM and RALS-LM test, respectively. LM and RALS-LM are invariant to the breaks periods. The critical values for LM and RALS-LM can be found Meng et al. (2014). Finally, ${ }^{* * *},{ }^{* *}$, and * denote statistical significance at the $1 \%, 5 \%$ and $10 \%$ levels, respectively.

\begin{tabular}{|c|c|c|c|c|c|c|}
\hline \multirow{2}{*}{ Country } & \multirow{2}{*}{$\begin{array}{l}L M \\
\tau_{L M}^{*}\end{array}$} & \multicolumn{2}{|c|}{ RALS-LM } & \multicolumn{2}{|c|}{$\widehat{T}_{B}$} & \multirow{2}{*}{$\widehat{\boldsymbol{k}}$} \\
\hline & & $\tau_{R A L S-L M}^{*}$ & $\widehat{\rho}^{2}$ & $\widehat{T}_{B 1}$ & $\widehat{T}_{B 2}$ & \\
\hline \multicolumn{7}{|c|}{ Panel A: With two breaks } \\
\hline Indonesia & $-4.525^{*}$ & $-5.263^{* * *}$ & 0.71 & 1996 & 2000 & 4 \\
\hline Malaysia & $-7.127^{* * *}$ & $-7.181)^{* * *}$ & 0.83 & 1981 & 2008 & 2 \\
\hline Philippines & $-5.179^{* *}$ & $-4.710^{* *}$ & 0.99 & 1981 & 1996 & 8 \\
\hline Singapore & -3.277 & -2.626 & 0.79 & 1977 & 2009 & 4 \\
\hline Thailand & $-6.759^{* * *}$ & $-6.426^{* * *}$ & 0.59 & 1980 & 1986 & 1 \\
\hline \multicolumn{7}{|c|}{ Panel B: With one break } \\
\hline Indonesia & $-3.998^{*}$ & $-3.567^{*}$ & 0.85 & 1996 & - & 6 \\
\hline Malaysia & $-5.628^{* * *}$ & $-5.606^{* * *}$ & 0.95 & 1977 & - & 2 \\
\hline Philippines & -3.099 & -3.009 & 0.99 & 1995 & - & 1 \\
\hline Singapore & -1.673 & -2.354 & 0.44 & 2006 & - & 6 \\
\hline Thailand & $-4.801^{* * *}$ & $-4.420^{* * *}$ & 0.54 & 1980 & - & 0 \\
\hline \multicolumn{7}{|c|}{ Panel C: With zero break } \\
\hline Indonesia & -2.280 & -1.821 & 0.83 & - & - & 1 \\
\hline Malaysia & $-4.668^{* * *}$ & -2.570 & 0.91 & - & - & 2 \\
\hline Philippines & -1.719 & -2.333 & 0.68 & - & - & 1 \\
\hline Singapore & -2.230 & -1.410 & 0.79 & - & - & 6 \\
\hline Thailand & -2.683 & -1.032 & 0.58 & - & - & 0 \\
\hline \multicolumn{7}{|c|}{ Panel D: ADF } \\
\hline Indonesia & -2.490 & & & & & 1 \\
\hline Malaysia & $-3.225^{*}$ & & & & & 0 \\
\hline Philippines & -1.189 & & & & & 1 \\
\hline Singapore & -0.560 & & & & & 0 \\
\hline Thailand & $-3.928^{* *}$ & & & & & 0 \\
\hline
\end{tabular}




\section{Appendix 2.}

\section{Using Zero/One/Two Breaks LM and RALS-LM Unit Root Test (RWTFP)}

This table reports the unit root test results for relative TFP. The sample period taken from 1968-2014 in our analysis. $\hat{k}_{\tau^{*}}$ stands for optimum lags selected using general to specific procedure. $\widehat{T}_{B}$ indicates the break periods. $\tau_{L M}^{*}$ and $\tau_{R A L S-L M}^{*}$ denote the test statistics for LM and RALS-LM test, respectively. LM and RALS-LM are invariant to the breaks periods. The critical values for LM and RALS-LM can be found Meng et al. (2014). Finally, ${ }^{* * *}{ }^{* *}$, and ${ }^{*}$ denote statistical significance at the $1 \%, 5 \%$ and $10 \%$ levels, respectively.

\begin{tabular}{|c|c|c|c|c|c|c|}
\hline \multirow{2}{*}{ Country } & \multirow{2}{*}{$\begin{array}{l}L M \\
\tau_{L M}^{*}\end{array}$} & \multicolumn{2}{|c|}{$R A L S-L M$} & \multicolumn{2}{|c|}{$\widehat{T}_{B}$} & \multirow{2}{*}{$\widehat{\boldsymbol{k}}$} \\
\hline & & $\tau_{R A L S-L M}^{*}$ & $\widehat{\rho}^{2}$ & $\widehat{T}_{B 1}$ & $\widehat{T}_{B 2}$ & \\
\hline \multicolumn{7}{|c|}{ Panel A: With Two breaks } \\
\hline Indonesia & $-6.367^{* * *}$ & $-6.351^{* * *}$ & 0.87 & 1997 & 2004 & 8 \\
\hline Malaysia & -3.290 & -2.657 & 0.99 & 1984 & 1987 & 6 \\
\hline Philippines & $-5.686^{* * *}$ & $-6.057^{* * *}$ & 0.85 & 1996 & 2004 & 1 \\
\hline Singapore & $-5.312^{* * *}$ & $-6.290^{* * *}$ & 0.75 & 1999 & 2004 & 2 \\
\hline Thailand & $-5.709^{* * *}$ & $-6.017^{* * *}$ & 0.72 & 1978 & 1983 & 3 \\
\hline \multicolumn{7}{|c|}{ Panel B: With one break } \\
\hline Indonesia & $-4.127^{* *}$ & $-4.676^{* * *}$ & 0.77 & 1997 & - & 8 \\
\hline Malaysia & -2.936 & -2.598 & 0.69 & 1996 & - & 6 \\
\hline Philippines & $-3.787^{*}$ & $-3.809^{* *}$ & 0.84 & 1990 & - & 1 \\
\hline Singapore & $-4.421^{* *}$ & $-4.564^{* * *}$ & 0.85 & 1995 & - & 2 \\
\hline Thailand & -3.337 & $-4.351^{* * *}$ & 0.46 & 1995 & - & 8 \\
\hline \multicolumn{7}{|c|}{ Panel C: With zero break } \\
\hline Indonesia & -2.037 & -1.705 & 0.86 & - & - & 1 \\
\hline Malaysia & $-2.925^{*}$ & -2.369 & 0.95 & - & - & 0 \\
\hline Philippines & -2.180 & -2.065 & 0.93 & - & - & 1 \\
\hline Singapore & -2.083 & $-3.457^{* *}$ & 0.73 & - & - & 2 \\
\hline Thailand & -2.757 & -2.254 & 0.75 & - & - & 0 \\
\hline \multicolumn{7}{|c|}{ Panel D: ADF } \\
\hline Indonesia & -2.095 & & & & & 1 \\
\hline Malaysia & $-3.245^{*}$ & & & & & 0 \\
\hline Philippines & -2.362 & & & & & 1 \\
\hline Singapore & -2.665 & & & & & 2 \\
\hline Thailand & $-3.193^{*}$ & & & & & 3 \\
\hline
\end{tabular}

